\title{
The effect of passive measures on thermal comfort and energy conservation. A case study of the Hot Summer and Cold Winter climate in the Yangtze River region
}

Article

Accepted Version

Creative Commons: Attribution-Noncommercial-No Derivative Works 4.0

Yao, R., Costanzo, V., Li, X., Zhang, Q. and Li, B. (2018) The effect of passive measures on thermal comfort and energy conservation. A case study of the Hot Summer and Cold Winter climate in the Yangtze River region. Journal of Building Engineering, 15. pp. 298-310. ISSN 2352-7102 doi: https://doi.org/10.1016/j.jobe.2017.11.012 Available at https://centaur.reading.ac.uk/74023/

It is advisable to refer to the publisher's version if you intend to cite from the work. See Guidance on citing.

Published version at: https://www.sciencedirect.com/science/article/pii/S235271021730308X

To link to this article DOI: http://dx.doi.org/10.1016/j.jobe.2017.11.012

Publisher: Elsevier

All outputs in CentAUR are protected by Intellectual Property Rights law, including copyright law. Copyright and IPR is retained by the creators or other copyright holders. Terms and conditions for use of this material are defined in the End User Agreement. 


\section{www.reading.ac.uk/centaur}

\section{CentAUR}

Central Archive at the University of Reading

Reading's research outputs online 


\section{Author's Accepted Manuscript}

The effect of passive measures on thermal comfort and energy conservation. A case study of the Hot Summer and Cold Winter climate in the Yangtze River region

Runming Yao, Vincenzo Costanzo, Xinyi Li, Qiulei Zhang, Baizhan Li

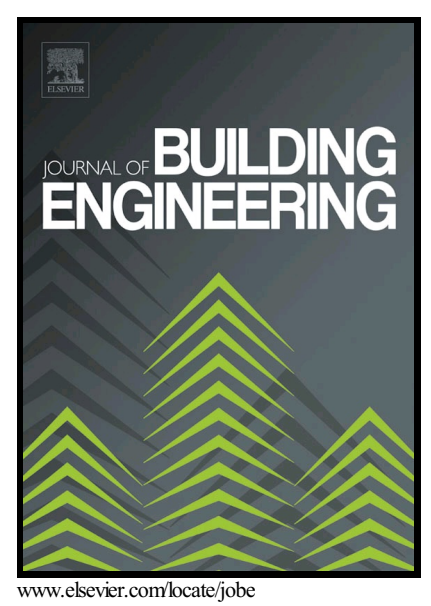

PII: S2352-7102(17)30308-X

DOI: $\quad$ https://doi.org/10.1016/j.jobe.2017.11.012

Reference: JOBE359

To appear in: Journal of Building Engineering

Received date: 1 June 2017

Revised date: 15 November 2017

Accepted date: 17 November 2017

Cite this article as: Runming Yao, Vincenzo Costanzo, Xinyi Li, Qiulei Zhang and Baizhan Li, The effect of passive measures on thermal comfort and energy conservation. A case study of the Hot Summer and Cold Winter climate in the Yangtze River region, Journal of Building Engineering, https://doi.org/10.1016/j.jobe.2017.11.012

This is a PDF file of an unedited manuscript that has been accepted for publication. As a service to our customers we are providing this early version of the manuscript. The manuscript will undergo copyediting, typesetting, and review of the resulting galley proof before it is published in its final citable form. Please note that during the production process errors may be discovered which could affect the content, and all legal disclaimers that apply to the journal pertain. 


\title{
ACCEPTED MANUSCRIPT
}

The effect of passive measures on thermal comfort and energy conservation.

\section{A case study of the Hot Summer and Cold Winter climate in the Yangtze River region}

\author{
Runming Yao ${ }^{1,3}$, Vincenzo Costanzo ${ }^{3}$, Xinyi $\mathrm{Li}^{1,2}, \quad$ Qiulei Zhang ${ }^{1,2}, \quad$ Baizhan $\mathrm{Li}^{* 1,2,3}$ \\ 1, Joint International Laboratory of Green Buildings and Built Environments, Ministry of \\ Education, Chongqing University, Chongqing, 400045, China;
}

2, National Centre for International Research of Low-carbon and Green Buildings, Ministry of Science and Technology, Chongqing University, Chongqing, 400045, China;

${ }^{3,}$ School of the Built Environment, University of Reading, Whiteknights, Reading, RG6 6AW, UK;

*Corresponding Author: Baizhan Li

Email: baizhanli@cqu.edu.cn

Postal Address: School of the Urban Construction and Environmental Engineering; Chongqing University, Campus B, Chongqing, China, 400045

\begin{abstract}
The energy consumption for heating and cooling of buildings in the cities located within the boundaries of the Hot Summer and Cold Winter (HSCW) zone in China is rapidly increasing due to the increased comfort expectations from well-resourced occupants. Guidance on how and to what extent it is possible to improve energy efficiency of buildings is thus required by policy makers as well as designers and building managers. The aim of this study is to demonstrate how the use of climate-sensitive passive design solutions can help the improvement of indoor thermal conditions while reducing the energy needs and ultimately carbon emissions. An extensive parametric analysis of several passive strategies such as building orientation, thermal insulation, glazing area, shading devices, air tightness and natural ventilation, is carried out for a typical apartment block located in the cities of Chongqing, Changsha and Shanghai, which lays respectively in the upper, middle and downstream of the Yangtze River. Detailed hourly dynamic simulations show how it is possible to extend the non-heating/cooling period and reduce the peak loads, highlighting the potentialities of each strategy according to different climate constraints. The recommended
\end{abstract}




\section{ACCEPTED MANUSCRIPT}

strategies provides quantitative guidance to either design of new or retrofitting of existing buildings. This research contributes to the building energy conservation knowledge for

policy-makers, developers and building designers with insight on the feasibilities of the application of passive measures for the residential buildings located in the Yangtze River region with hot summer and cold winter climates.

Keywords: passive design, residential building, parametric analysis, dynamic simulations, thermal comfort

\section{Introduction}

The increasing concern about the environmental impact of buildings and the quality of their internal environments has raised the debate as to the role architects should play in the environmental design of buildings. Passive design, also known as ‘bio-climatic design', helps maximise occupant's comfort and health by harmonizing local climatic and site conditions with architectural design and building technologies [1]. As highlighted in their pioneering works by Olgyay [2] and Givoni [3], the concept of passive design is to heat, to cool and to light buildings using ingenious design techniques and materials by reducing or even without using any energy system. The measures mainly include building form, shape, orientation, insulation, thermal mass, natural ventilation, shading and air tightness. It is hard to find an original clear definition that led to a categorization of the passive design concept. First prototypical realizations can be recognized in the so-called solar passive buildings, which provide effective energy savings during buildings operation especially in the winter season thanks to large solar harvesting facades oriented towards the equator. There have been many studies on this concept starting from the 1970s as an answer to the world energy crisis arisen at that time [4-6].

It is just in 1991, when the first Passivhaus was effectively built in Darmstadt-Kranichstein (Germany), that strict requirements for achieving comfort and energy performance targets appeared, informing both designers and final users. As stated by Dr. Wolfgang Feist, a Passivhaus "makes efficient use of the sun, internal heat sources and heat recovery, rendering conventional heating systems unnecessary throughout even the coldest of winters. During warmer months, Passive Houses make use of passive cooling techniques such as strategic shading to keep comfortably cool" [7]. According to this definition, the Passivhaus 


\section{ACCEPTED MANUSCRIPT}

should not be just a brand name but a construction concept that can be applied everywhere, although some authors raised concerns about its applicability in warm climates [8]. More in detail, the original standard requires to achieve energy needs for space heating lower than 15 $\mathrm{kWh} \mathrm{m}^{-2} \mathrm{y}^{-1}$ and total primary energy needs (heating, domestic hot water and electrical appliances) below $120 \mathrm{kWh} \mathrm{m}^{-2} \mathrm{y}^{-1}$. Air infiltrations should be kept below 0.6 Air Changes per Hour $(\mathrm{ACH})$ at a pressure difference of $50 \mathrm{~Pa}$ [7]. The extended version of the standard for warm climates demands also for keeping the sensible energy demand for space cooling below $15 \mathrm{kWh} \mathrm{m}^{-2} \mathrm{y}^{-1}$ and including cooling in the calculation of the total primary energy needs. Under these circumstances, a lower air tightness is allowed (1 $\mathrm{ACH}$ at $50 \mathrm{~Pa})$ [9].

Building on the generic passive design principles and on the main findings of the Passivhaus Institute, several other international organizations are constantly paying attention to this field of research. As an example, the Fraunhofer Institute for Building Physics in Stuttgart (Germany) and the Building Research Establishment in Watford (UK) are two of the forefront institutions in the field of the energy efficiency and indoor climate studies in Europe. In the US, the Center for the Built Environment and the Center for Green Buildings and Cities hosted by the Berkeley and Harvard university respectively, are leaders in comfort studies and technology transfer.

International associations such as the Passive and Low Energy Architecture (PLEA) are engaged in a worldwide discourse on sustainable architecture and urban design through annual international conferences, workshops and publications [10]. The first PLEA international conference was held in early 1980s and until 2016 there were 32 annual conferences held.

This research stream pushed the legislators to make low-energy passive design strategies compulsory for new buildings. A milestone in this sense is the introduction of the nearly Zero Energy Building (nZEB) concept within the European countries as prescribed by the EU Directive 2010/30 [11]. For achieving such high-energy performances, "the nearly zero or very low amount of energy required should be covered to a very significant extent by energy from renewable sources, including energy from renewable sources produced on-site or nearby". Practically, on the one hand it is required to build very performing passive houses, while on the other hand to supply the remaining energy needs by means of renewable energy resources.

As for China, there are many evidence about the climatic-responsive passive design concepts being applied since vernacular architectural design [12]. In fact, many passive design measures have been successfully employed by local builders: the north-south plan orientation 


\section{ACCEPTED MANUSCRIPT}

to balance solar gains; window openings designed to maximise the potential of natural ventilation from local winds; external overhangs protecting from direct sunlight during summer and courtyards to provide a filtering space with the surroundings are amongst the most common [13-16].

In 2009, the Ministry of Housing and Urban-Rural Development (MOHURD) and the German Energy Agency (DENA) conducted a China Passivehouse Demonstration International Collaboration Project, aimed to develop China-context low energy building standard applicable to the China's climatic characteristic, building types and working/living styles [17-18]. Since then, the passive house approach has been widely promoted starting from the northern China and spreading to the southern China. For example, Dan et al. [19] studied the envelope insulation in the cold climates through an exemplar building and addressed the importance of insulation in northern China. In recent years, many Chinese scholars have been paying attention on its feasibility and conducted case studies on passive house approach in the Hot Summer and Cold Winter (HSCW) zone [20-24] in order to gain better understanding of the application of passive design and technologies in this region. It poses great challenges due to the climatic characteristics of the HSCW zone as categorized by the Chinese Standard of Climate Regionalization for Architecture [25]. A number of issues have been concerned such as the overheating risk due to the super insulation, air quality issue due to the air tightness and the residents' habit of opening windows in this region.

In addition to the climate factors, the study of low energy buildings are in high demand here as in the HSCW zone there is a building stock with some 9 billion square meters $(66 \%$ residential and 34\% public, according to the 2014 Annual Report on China Building Efficiency from Tsinghua University [26]). There is an urgent and growing demand to improve summer and winter indoor thermal environment in this region, where with no doubt the energy demand for heating and cooling will increase significantly thus exacerbating carbon emissions and environmental pollution [27].

It is increasingly recognised that, ultimately, a building's performance is largely determined by its 'strategic' design as considered within the earliest stages of a project. For example, decisions about plan depth, orientation and fenestration (the glazing scheme) are all key strategic elements of the design, which influence the potential for daylight and natural ventilation, which in turn determine the demand for heating and cooling. These early design decisions have inevitable knock-on effects for plant and equipment, which have a major impact on building energy performance. 


\section{ACCEPTED MANUSCRIPT}

As the nature of 'bio-climatic design' is to align with the local climates, it is essential to assess the effectiveness of the passive solutions at the strategic design stage based on the climatic characteristics [28]. In order to answer the question 'to what extent the passive solutions can improve indoor thermal comfort and energy consumption for the cities alongside the Yangtze River valley region with hot summer and cold winter climatic characters in China?', this research focuses on strategic studies to identify the optimised passive solution by simulations. The main novelty of the study is the systematic application of the concept of extending the non-heating/cooling periods to an extensive parametric analysis of the features mostly affecting indoor comfort conditions. Based on the comfort criteria, best and worst scenarios in terms of energy consumption are discussed in detail for a climate where heating and cooling are both of concern, by including latent loads in the calculation as well.

It is expected to provide strategic quantitative guidance to the policy-makers, developers and building designers in the practice of achieving low energy consumption while retaining good thermal conditions.

\section{Brief literature review on passive design solutions}

The basic principle of any passive design strategy is to protect the building shell from heat loss in winter and from unwanted heat gains in summer. In order to achieve the required internal temperatures, the heat loss and gains should be balanced; otherwise, auxiliary heating and cooling will be required for the most of occupancy time [29]. To achieve this design goal, several technological solutions and techniques have been implemented and successfully tested, as shown in the following.

\subsection{Traditional design strategies for cold climates}

In order to reduce the heat losses, increasing the thermal resistance of the opaque envelope components (e.g. walls and roof) by adding insulation layers can help reduce the heating demand, and generally results in higher indoor temperatures [30]. The use of double or triple glazing, provided with thermal cut and filled with an inert gas, strongly decreases the outflow of heat from the windows [31]. For particularly cold climates, a low-emissive layer could be applied to the inner pane to further increase the window's insulation capabilities. 


\section{ACCEPTED MANUSCRIPT}

Moreover, the movement of air into and out of the building which is not for the specific and planned purpose of exhausting stale air or bringing in fresh airflow through envelope commonly known as air leakage - should be reduced as well [32]. Air leakage should never be considered as acceptable natural ventilation because it cannot be controlled or filtered and will not provide adequate or evenly distributed ventilation. Ventilation of a building should never rely on air leakage, but should be provided by purpose-designed systems based on the assumption that the envelope will be relatively airtight [33]. A well-insulated and airtight building shell would perform well during the winter season, especially if some form of heat storage is adopted meantime.

The first concept of heat storage mechanism studied at large scale for building applications was that of Trombe walls. They are glazed walls facing the equator with a buffer layer of air embedded between the window and a highly absorbing surface (i.e. with a high capacity of absorbing the energy coming from the solar radiation). Akbari and Borgers [34] studied the airflow behaviour in the air layer of the Trombe wall while Warrington and Ameel [35] carried out experiments on the heat transfer mechanism of natural convention between the wall and the room.

Similarly to Trombe walls, heat storage materials can be used to store heat directly (without making use of a thermal medium such as air) for flexible use according to the change of weather conditions outdoors. Sensible heat storage materials, such as water tanks and rock beds, can store heat from the sunshine in the daytime and send it out at night, using the greenhouse effect due to natural convection [36].

On the other hand, latent heat storage materials such Phase Change Materials (PCM) can be employed as well and coupled with a special ventilation system that utilizes the large temperature difference from daytime to night-time [37].

\subsection{Traditional design strategies for hot climates}

In buildings with high internal gains and during the summer season, the effect of insulation and air tightness on total energy use requires careful assessment. Removal of heat gain will become more reliant on ventilation if the building fabric cannot readily dissipate heat gains. Natural ventilation can take away the indoor heat and humidity and provide fresh air to improve indoor comfort conditions when the outdoor climate is comfortable. It is one of the most impacting factors for a building to realize the function of thermal comfort control [38]. The building fabric should be as airtight as possible to take advantage of a well-designed 


\section{ACCEPTED MANUSCRIPT}

ventilation strategy: 'build tight, ventilate right' [39] is true for both mechanical and naturally ventilated buildings.

Nonetheless, thermal mass has a significant effect on energy savings and should be considered as well in building design according to the building type and function [40]: night cooling, if combined with components with high thermal mass, can be used as a means of avoiding or minimising the need for mechanical refrigeration in a building. Indeed, during the summer ambient air is circulated through the building at night, cooling the building fabric; this stored cool energy is then available the next day to offset heat gains, thereby reducing or eliminating the need for mechanical refrigeration to maintain thermal comfort [41]. Where natural ventilation is deemed necessary, the operation of windows should be explained to the management and other building occupants, and showed possibly be automated [38]. Effective automatic control would need to be integrated with the rest of the control system and provide management feedback.

Other strategies involve shading from the sun's action and the provision of a thermal buffer between the indoor and outdoor environment to adjust sunlight, ventilation rates and the thermal environment inside the house [40]. Shading design becomes one of the most important passive design factors to fulfil the indoor temperature and humidity requirements for comfort purposes. The provision of sun shading for doors and windows would in fact reduce the amount of heat gains through glazed surfaces, whereas other forms of external shading such as verandas would decrease the amount of surfaces directly exposed to sun's radiation [42].

Moreover, the use of green materials and selective coatings to be applied to the external building surfaces (roofs and walls mainly) can strongly reduce the amount of the heat flux incoming through the envelope by reflecting most of the sunlight impinging on them [43-44]. It is worth to note that when green materials are used for roofs application, the additional thermal mass provided by the growing media can help delay and attenuate the thermal wave due to the combined action of temperature and solar radiation [45].

It is possible to extend the concept of increasing the reflected component of solar radiation also to the windows by using reflective or dynamic glazing (i.e. able to dynamically adapt its optical properties according to an external input). Both these technological approaches proved to be very efficient in reducing the cooling loads and lowering indoor temperatures, though the reduction of the visible light component should be carefully addressed to avoid the increase of artificial lighting demand [46]. 


\section{ACCEPTED MANUSCRIPT}

\subsection{Design strategies for mixed climate conditions}

For those climates that are not clearly classifiable as purely 'cold' and 'hot' it is usually required a mix of the previous design solutions to maximise comfort conditions and reducing the energy demand for space heating and cooling. However, the trade-offs between heat gains and losses need to be studied more in detail as the optimal design configuration is not trivial: as an example, although night ventilation together with massive walls is traditionally regarded as a good passive cooling technique, it proves to be not that effective when outdoor temperatures are quite high continuously in a certain long period. These and other aspects will be explained in detail in the next sections. Therefore, it poses challenges in determination of the selection of passive measures to improve thermal comfort for the climate need both heating and cooling.

\section{Methodology}

\subsection{Hypothesis/concept}

This study builds upon the hypothesis that passive solutions can reduce the heating and cooling demand for indoor thermal comfort of buildings located in the Yangtze River Valley region within the HSCW zone. The non-heating/cooling period can be extended, and the peak loads can be reduced due to the adoption of passive solutions, which in the end will reduce the electricity consumption used for heating and cooling. To support this statement, the present research makes use of annual dynamic energy simulations of a typical apartment block located in different cities of the region. Different climatic conditions will thus reveal the potential of several technological solutions to be successfully implemented. Along with the use of common metrics such as the number of comfort hours and the Energy Use Intensity (EUI) for heating and cooling, an index called PEPS (Potential Effectiveness of Passive Solutions) is introduced. It expresses the percent improvement of comfort hours when passive strategies are implemented with respect to a base case:

$$
\text { PEPS }=\frac{h_{\text {comf_passive }}-h_{\text {comf_base }}}{8760}
$$

For this exploratory study, thermal comfort is assumed to depend mainly on indoor air temperature values, whose comfort boundary is set in the range of 18 to $26^{\circ} \mathrm{C}$ according to local residential buildings design standards [47-48], and on humidity values (30 to $70 \%$ range 


\section{ACCEPTED MANUSCRIPT}

according to the Design Code for Heating Ventilation and Air Conditioning of Civil Buildings [49]). These comfort boundaries are also used when evaluating the energy needs

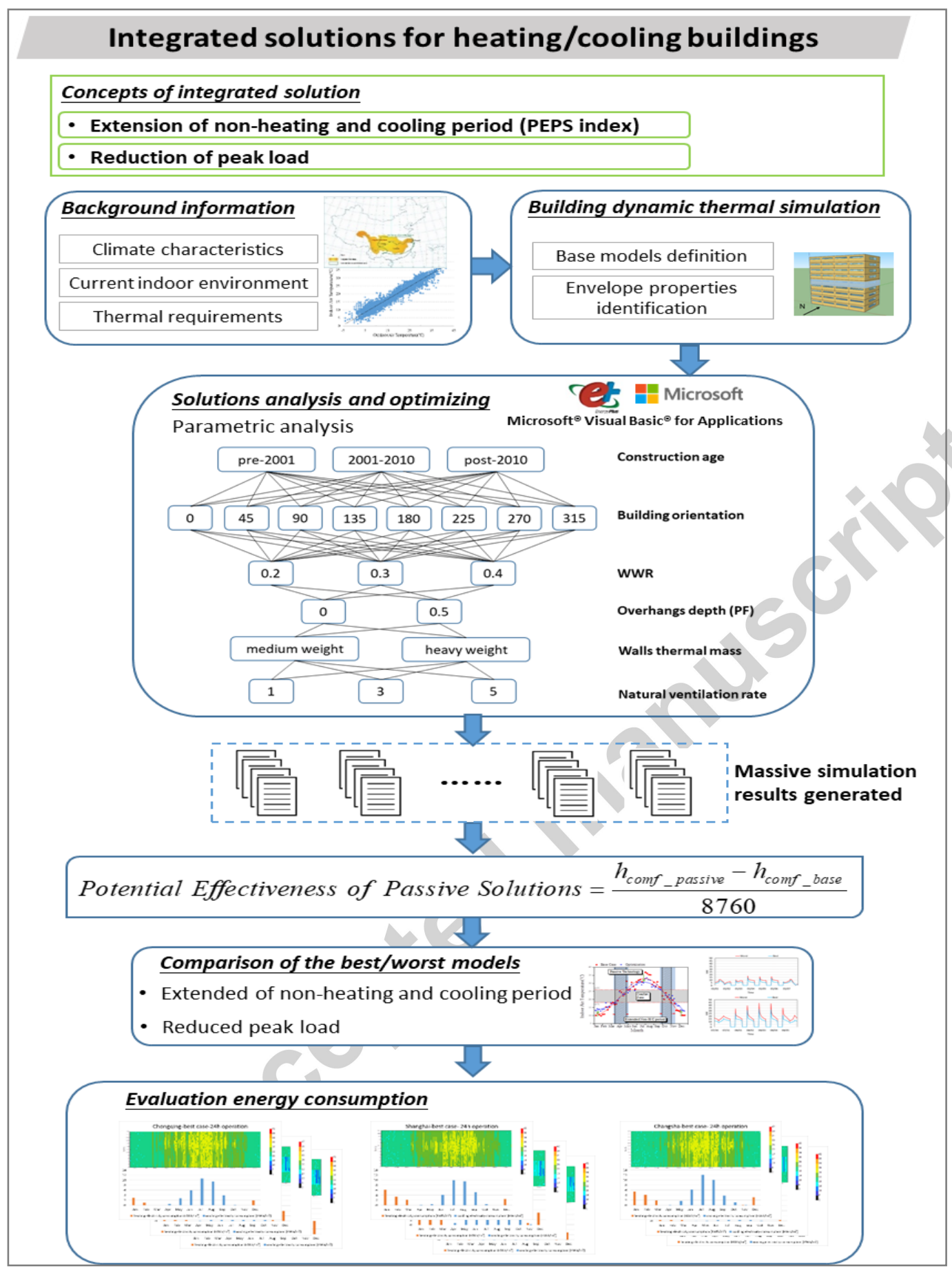

during HVAC operation, according to two different occupancy scenarios: i) $24 \mathrm{~h}$ availability throughout the year and ii) cooling available 24 hours on weekends and from 6PM to 8AM on weekdays when occupants are supposed to be at home after work and heating available from 7AM to 11PM on weekends and from 6PM to 11PM on weekdays. The overall framework structure of this paper is presented in Figure 1.

Figure 1. Framework of this study 


\section{ACCEPTED MANUSCRIPT}

\subsection{Geographic and climatic characteristics}

In the Hot Summer and Cold Winter zone in China, there are about 16 provinces with 550 million citizens, $53 \%$ of whom live in cities. Relatively well-resourced city residents without space heating systems use their air-conditioning units with controls set in reverse to achieve winter warmth. A recent survey carried out in six cities of the HSCW zone shows how average indoor air temperatures range between $8-14^{\circ} \mathrm{C}$ (coolest month) and $25-35^{\circ} \mathrm{C}$ (hottest month), being the lowest and highest values recorded $-2^{\circ} \mathrm{C}$ and $41^{\circ} \mathrm{C}$ respectively [50].

The location of the cities chosen in this study is shown in Figure 2. The cities chosen are Chongqing, Changsha and Shanghai, which are geographically located in the upper, middle and downstream of the Yangtze River. Moreover, they show some climatic differences that are able to highlight the potential of different passive strategies. As an example, Chongqing stands out because of its high temperatures and low wind velocities, whereas Shanghai shows the highest ventilation potential, mainly because of its proximity to the Eastern China Sea. These differences have emerged by using the same approach developed by Costanzo and Donn to evaluate the passive cooling potential of natural ventilated office buildings [51]. The method makes use of summer and winter average values of environmental parameters such as air temperature, relative humidity, global horizontal solar radiation and wind velocity, coupled with a visual examination of Typical Meteorological Year (TMY) weather data on psychometric charts. In this way, the simplifications of the traditional Köppen-Geiger classification [52] are overcome, making the comparison among different climates more meaningful under a building physics perspective.

The values of the environmental parameters of each city are listed in Table 1 as average monthly values for the winter season (December to February) and the summer season (June to August) respectively. 


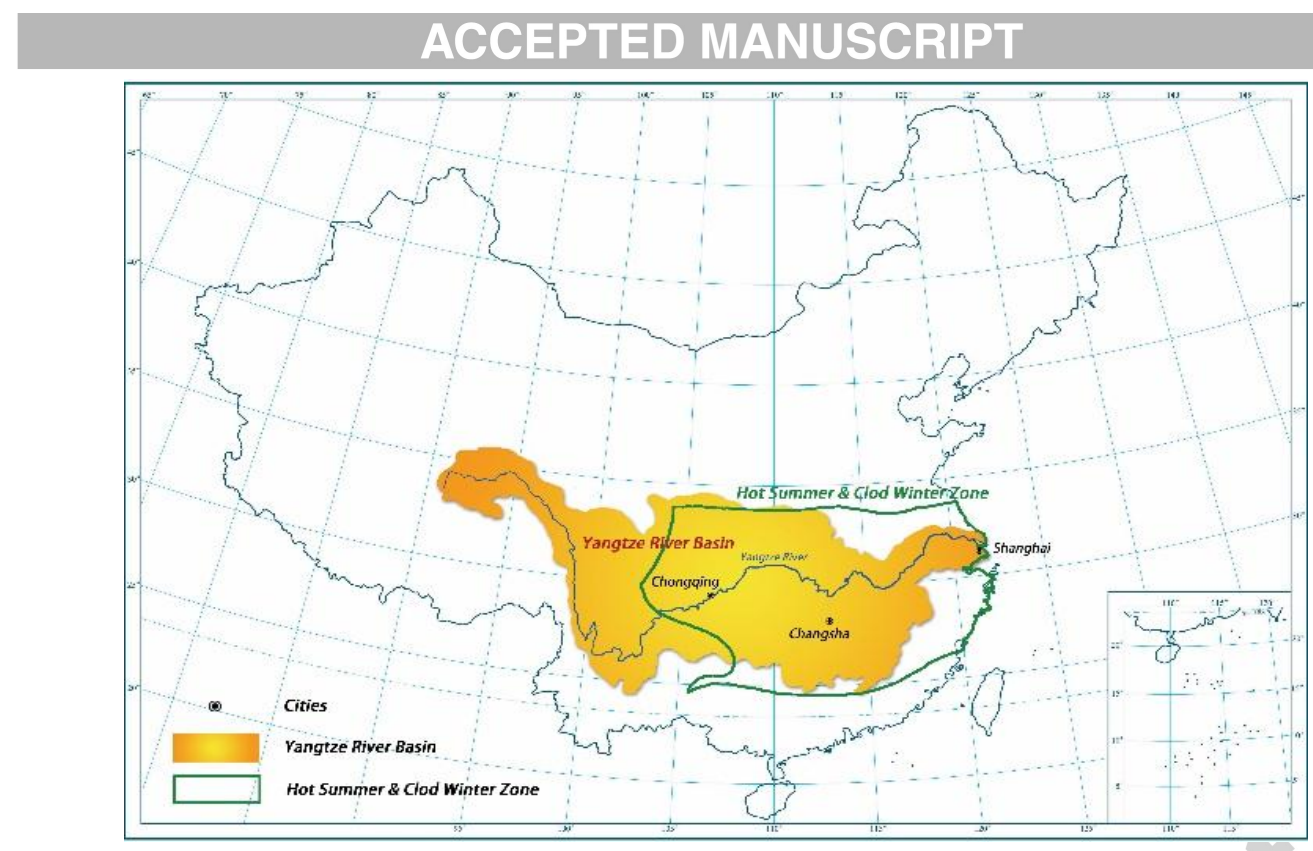

Figure 2. Locations of the study cities in YRD region

Table 1. Climatic characteristics of the study cities

\begin{tabular}{|c|l|l|l|l|l|l|}
\hline $\begin{array}{c}\text { Köppen-Geige } \\
\text { r classification }\end{array}$ & City & $\begin{array}{l}\text { Dry bulb } \\
\text { temperature } \\
\left({ }^{\circ} \mathbf{C}\right)\end{array}$ & $\begin{array}{l}\text { Relative } \\
\text { humidity } \\
(\%)\end{array}$ & $\begin{array}{l}\text { Global } \\
\text { horizontal } \\
\text { radiation } \\
\left(\mathbf{W h m}^{-2}\right)\end{array}$ & $\begin{array}{l}\text { Wind } \\
\text { speed } \\
\left(\mathbf{m s}^{-1}\right)\end{array}$ & $\begin{array}{l}\text { HDD/CDD } \\
\left({ }^{\circ} \mathbf{C}\right)^{*}\end{array}$ \\
\hline \multirow{2}{*}{$\begin{array}{c}\text { Humid } \\
\text { subtropical } \\
(\text { Cfa })\end{array}$} & Chongqing & 9.2 & 85 & 39.7 & 1.3 & 1164 \\
\cline { 2 - 8 } & Changsha & 6.5 & 82 & 71.5 & 2.3 & 1520 \\
\cline { 2 - 8 } & Shanghai & 6.1 & 72 & 104.8 & 3.1 & 1598 \\
\hline \multirow{2}{*}{\begin{tabular}{l|l|l|l|l|l|} 
Summer \\
Hubtropical \\
$($ Cfa $)$
\end{tabular}} & Changsha & 27.1 & 79 & 159.5 & 1.6 & 1279 \\
\cline { 2 - 8 } & Shanghai & 26.2 & 82 & 185 & 1.9 & 1311 \\
\hline
\end{tabular}

*HDD/CDD are both calculated on a baseline of $18.3{ }^{\circ} \mathrm{C}$ according to the Climate Design Data 2009 ASHRAE Handbook [53]

A field study of indoor thermal environment and comfort in the HSCW zone carried out during the period from 2008 to 2011 including the cities of Chongqing, Wuhan, Chengdu, 


\section{ACCEPTED MANUSCRIPT}

Changsha and Hangzhou shows strong correlation between the indoor and outdoor air temperatures, and thus poor thermal environments. Figure 3 shows how a linear relationship well represents the correlation between indoor and outdoor environments, further justifying the need of a study aimed at improving indoor comfort conditions.

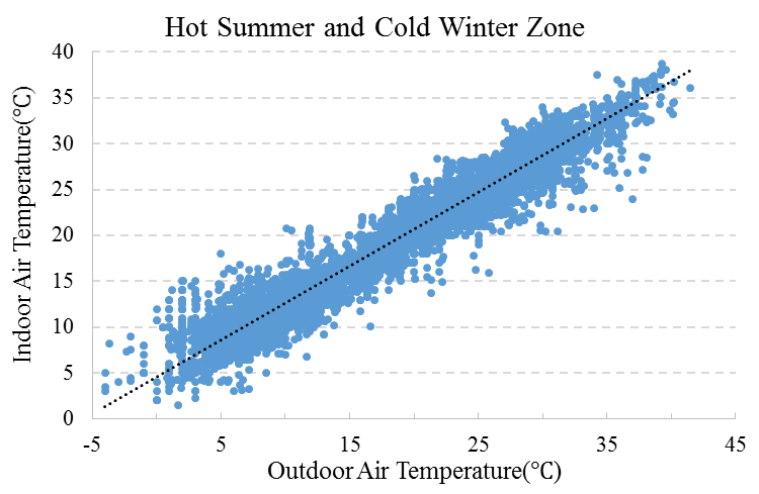

Figure 3. Relationship between indoor and outdoor air temperatures in the HSCW zone

\subsection{Definition of the base models}

An extensive parametric analysis of different passive design strategies is carried out by using dynamic thermal simulations under both free running conditions, i.e. without the operation of any mechanical system to provide heating or cooling, and when a thermostatic control is set. Parametric analysis has been extensively used in building performance simulation field, and it is widely recognized as a powerful approach to design low-energy and comfortable buildings [54-56]. Moreover, building simulation supports the design and operation of performance based buildings by objectively comparing alternative design solutions, thus providing the most cost-effective way for strategical studies [57-59].

Among variety of simulation packages, EnergyPlus v8.4 is adopted mainly due to its abilities in thermal and airflow modeling [60]. The middle floor of a typical medium-rise apartment block (see Figure 4) is chosen for simulation purposes, being this residential typology very common in Chinese megacities. The floor is made up of four apartments $\left(306 \mathrm{~m}^{2}\right)$ and two stairwells $\left(72 \mathrm{~m}^{2}\right)$, with a north-south orientation for the main facades. The entire floor is modelled with a single thermal zone for what concerns the apartments, and with two separate thermal zones for the stairwells. In fact, preliminary simulations revealed no significant differences in indoor temperature distributions for the 4 apartments if individually considered. Wall surfaces are exposed to the outdoor environment, whereas floors and ceilings are considered adiabatic. Different Window to Wall Ratio (WWR) are used 


\section{ACCEPTED MANUSCRIPT}

according to the orientation: for the north orientation a value of 0.2 is retained, whereas for the remaining west, east and south orientations the WWR is set to 0.3. This basic geometrical configuration has been kept constant for the parametric study, except for: i) the amount of glazed surfaces facing south (WWR of 0.2 and 0.4 have been explored in order to evaluate the role played by windows in determining indoor comfort conditions and heat gains), ii) the main building orientation (see the next section for a detailed description of the parametric setup).
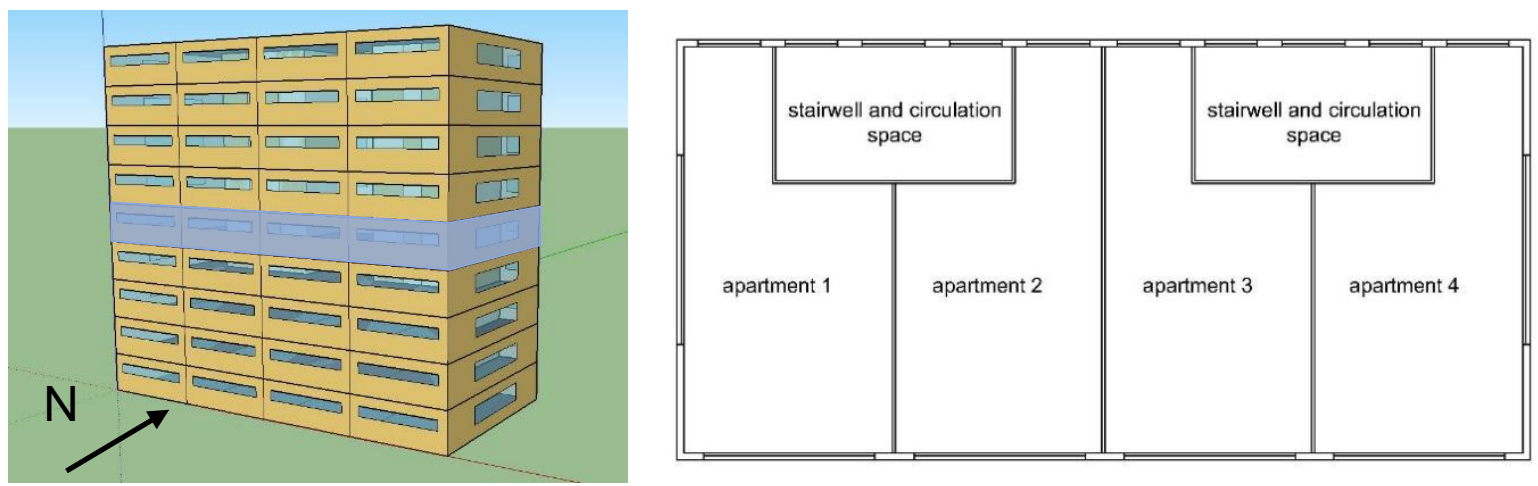

Figure 4. View of the thermal model with the typical middle floor highlighted in blue (on the left) and its internal layout (on the right)

For what concerns the envelope properties, this study considers typical constructions from different ages, in order to appreciate the role played by different materials, stratifications and air tightness values. Construction ages, as well as all of the information needed for thermal modelling, have been gathered from national and industrial design standards [47-48] and are summarized in Table 2.

Table 2. Summary of design standards used for creating thermal models and envelope characteristics for the base configurations

\begin{tabular}{|c|c|c|c|c|c|c|c|c|}
\hline \multirow{3}{*}{$\begin{array}{c}\text { Construction } \\
\text { age and } \\
\text { relevant } \\
\text { standard }\end{array}$} & \multicolumn{4}{|c|}{ Envelope thermal characteristics } & \multirow{2}{*}{$\begin{array}{c}\text { HVAC systems } \\
\text { (heat pumps) } \\
\text { Heating } \\
\text { COP/Cooling } \\
\text { EER }\end{array}$} & \multicolumn{3}{|c|}{ Internal loads } \\
\hline & Walls & Winc & & Air & & Occupants & Equipment & Lighting \\
\hline & $\begin{array}{l}U \text {-values } \\
\left(W m^{-2} K^{-1}\right)\end{array}$ & $\begin{array}{c}U \text {-values } \\
\left(W m^{-2} K^{-1}\right)\end{array}$ & $S H G C$ & $\overline{A C H}\left(h^{-1}\right)$ & $(-)$ & $\left(p^{-2}\right)$ & $\left(W m^{-2}\right)$ & $\left(W m^{-2}\right)$ \\
\hline pre-2001 & 1.97 & 5.74 & 0.85 & 2 & $1 * / 2.2$ & 0.03 & 4.3 & 6 \\
\hline
\end{tabular}




\begin{tabular}{|c|c|c|c|c|c|c|c|c|}
\hline $\begin{array}{l}\text { (JGJ 134-2001 } \\
\text { Standard) }\end{array}$ & & & & & & & & \\
\hline $\begin{array}{l}2001-2010 \\
(J G J 134-2001)\end{array}$ & 1.03 & 2.80 & 0.48 & 1 & $1.9 / 2.3$ & 0.03 & 4.3 & 6 \\
\hline $\begin{array}{l}\text { post-2010 } \\
(J G J 134-2010)\end{array}$ & 0.83 & 2.67 & 0.34 & 1 & $1.9 / 2.3$ & 0.03 & 4.3 & 6 \\
\hline
\end{tabular}

*electric heater efficiency value

**according to the occupancy profile defined in [61]

The use of typical constructions allows using the outcomes of the simulations not only during the design stage of new buildings, but also for the refurbishment of existing ones. More in detail, external walls are made up of solid clay bricks for the oldest construction period (pre-2001) and of concrete cellular blocks for the latest two periods (2001-2010 and post-2010). In both cases, a layer of cement mortar covers the structure internally and externally while an EPS panel of varying thickness is placed when needed on the outward face of the walls to approach the U-values prescribed by the standards.

Floors are made up of reinforced concrete covered by a cement mortar layer on both faces; the outer face presents also a cement layer covered by tiles and by an XPS panel of varying thickness for the two latest construction periods.

Windows are single-glazed clear panes (with a solar transmittance of 0.82) for the oldest constructions, whereas they are double-glazed for the two latest construction periods. In these cases, the inner pane is clear while the outer pane is reflective with a solar transmittance value of 0.44 .

As for the air tightness of the envelope, a constant infiltration rate of 2 Air Changes per Hour $(\mathrm{ACH})$ is used for the buildings realized before 2001, while a value of 1 is adopted for the latest two construction ages. Internal gains consist of people (involved in sedentary activities during the occupancy period), lights and electric equipment (both are turned on during the occupancy period when people are at home), and their respective values the same for each construction period as suggested by the standards (see Table 2).

Finally, electric heat pumps provide space heating and cooling for all construction periods except for the first one (pre-2001), where space heating is given by means of electric heaters.

\subsection{Parametric analysis}




\section{ACCEPTED MANUSCRIPT}

The building characteristics that have been varied in the parametric analysis are listed in Table 3 together with the number of variations and the values assumed for each iteration.

Some of them are similar to those explored by Naboni et al. [62], but differently this work does not make use of brute-force simulations to find the optimal energy consumption of a generic building type, but rather of a typical residential building with some known (i.e. fixed) characteristics.

Besides the construction ages defined in the previous section, some geometrical features such as the building orientation ( 8 main orientations, with a $45^{\circ}$ step increment), the WWR and the provision of external overhangs with different depths for the south-oriented windows are considered. In particular, a Projection Factor (PF) is introduced, defined as the ratio of the overhang depth to the window height, and it is used to study different external shading configurations.

Then, different thermal mass for the external walls are explored (called medium-weight walls and heavy-weight walls in the following, see Table 4 for their detailed properties) to see to what extent these configurations, together with different insulation levels, can store the heat and improve indoor comfort conditions. This helps giving a first order estimate of the influence of thermal inertia especially when natural ventilation strategies are used, which is supposed to happen whenever the following conditions are met altogether: i) outdoor temperature is between $18^{\circ} \mathrm{C}$ to $26^{\circ} \mathrm{C}$ and ii) wind speed is less than $20 \mathrm{~m} / \mathrm{s}$. The number of maximum $\mathrm{ACH}$ achievable when natural ventilation is employed have been varied parametrically. This basic control strategy on the one hand would avoid an inflow of air that is too fast and may disturb the occupants, and on the other hand guarantee a positive effect brought by outdoor air flow. Although higher ACH values could be theoretically achieved even in densely built urban environments [51], the values explored in this work are 1, 3 and 5 respectively. In fact, this conservative assumption both avoid to overestimate the benefits achievable when naturally ventilating and also accounts for a saturation effect that for buildings with low internal gains - such as residential ones - usually occurs for ACH higher than five [41].

Table 3. Parametric variations of different building features

\begin{tabular}{|l|l|l|}
\hline Parameters & Values & Variations \\
\hline Construction age & pre-2001, & 3 \\
& $2001-2010$, & \\
\hline
\end{tabular}




\begin{tabular}{|l|l|l|}
\hline & post-2010 & \\
\hline Building orientation ( ${ }^{\circ}$ clockwise) & $\begin{array}{l}0,45,90,135, \\
180,225,270, \\
315\end{array}$ & 8 \\
\hline WWR & $0.2,0.3,0.4$ & 3 \\
\hline Overhangs depth (PF) & $0,0.5$ & 2 \\
\hline Walls thermal mass & $\begin{array}{l}\text { medium weight, } \\
\text { heavy weight }\end{array}$ & 2 \\
\hline Natural ventilation rate $(\mathrm{ACH})$ & $1,3,5$ & 3 \\
\hline
\end{tabular}

Table 4. External walls thermal characteristics

\begin{tabular}{|c|c|c|c|c|c|}
\hline $\begin{array}{l}\text { Walls } \\
\text { type }\end{array}$ & $\begin{array}{l}\text { Construction } \\
\text { age }\end{array}$ & $\begin{array}{l}\text { U-value } \\
\left(\mathrm{Wm}^{-2} \mathrm{~K}^{-1}\right)\end{array}$ & $\begin{array}{l}\text { Thermal } \\
\text { mass }\left(\mathrm{kgm}^{-2}\right)\end{array}$ & $\begin{array}{l}\text { Thermal } \\
\text { capacity } \\
\left(\mathrm{kJK}^{-1}\right)\end{array}$ & $\begin{array}{l}\text { Thermal inertia } \\
\left(\mathrm{W}^{2} \mathrm{sm}^{-4} \mathrm{~K}^{-2}\right) 10^{-3}\end{array}$ \\
\hline \multirow{3}{*}{$\begin{array}{l}\text { medium } \\
\text { weight }\end{array}$} & pre-2001 & 1.97 & \multirow{3}{*}{292} & \multirow{3}{*}{307} & \multirow{3}{*}{2612} \\
\hline & 2001-2010 & 1.03 & & & \\
\hline & post-2010 & 0.83 & & & \\
\hline \multirow{3}{*}{$\begin{array}{l}\text { heavy } \\
\text { weight }\end{array}$} & pre-2001 & 1.97 & \multirow{3}{*}{418} & \multirow{3}{*}{440} & \multirow{3}{*}{7163} \\
\hline & $2001-2010$ & 1.03 & & & \\
\hline & post-2010 & 0.83 & & & \\
\hline
\end{tabular}

\subsection{Definition of the best/worst models and energy analysis}

The parametric study aims at providing a preliminary base to identify the optimal combination of the different design measures described in Table 3 for each study city. Given the high number of models simulated for each city, thermal comfort criteria have been used for the selection of the best performing ones. In detail, these are the models showing the highest number of comfort hours throughout the year under free-running conditions.

Conversely, the worst ones are those with the lowest proportion of comfort hours in a year. The best and worst models have been compared, for every city, under both free-running conditions and under thermostatic control, thus showing the potential of passive solutions to 


\section{ACCEPTED MANUSCRIPT}

improve indoor conditions for the occupants as well as reducing the energy needs for space heating and cooling.

\section{Results and Discussion}

\subsection{Extended non-heating and cooling period}

The outcomes of the simulations for the best and worst scenarios of every city are shown here in terms of weekly averaged indoor temperatures (Figure 5) and hourly indoor temperature distribution (Figure 6), thus showing their peculiarities due to climatic differences. Table 5 summarizes the best passive solutions and their PEPS Index, while single subsections discuss the main findings and suggests specific measures tailored for every city.
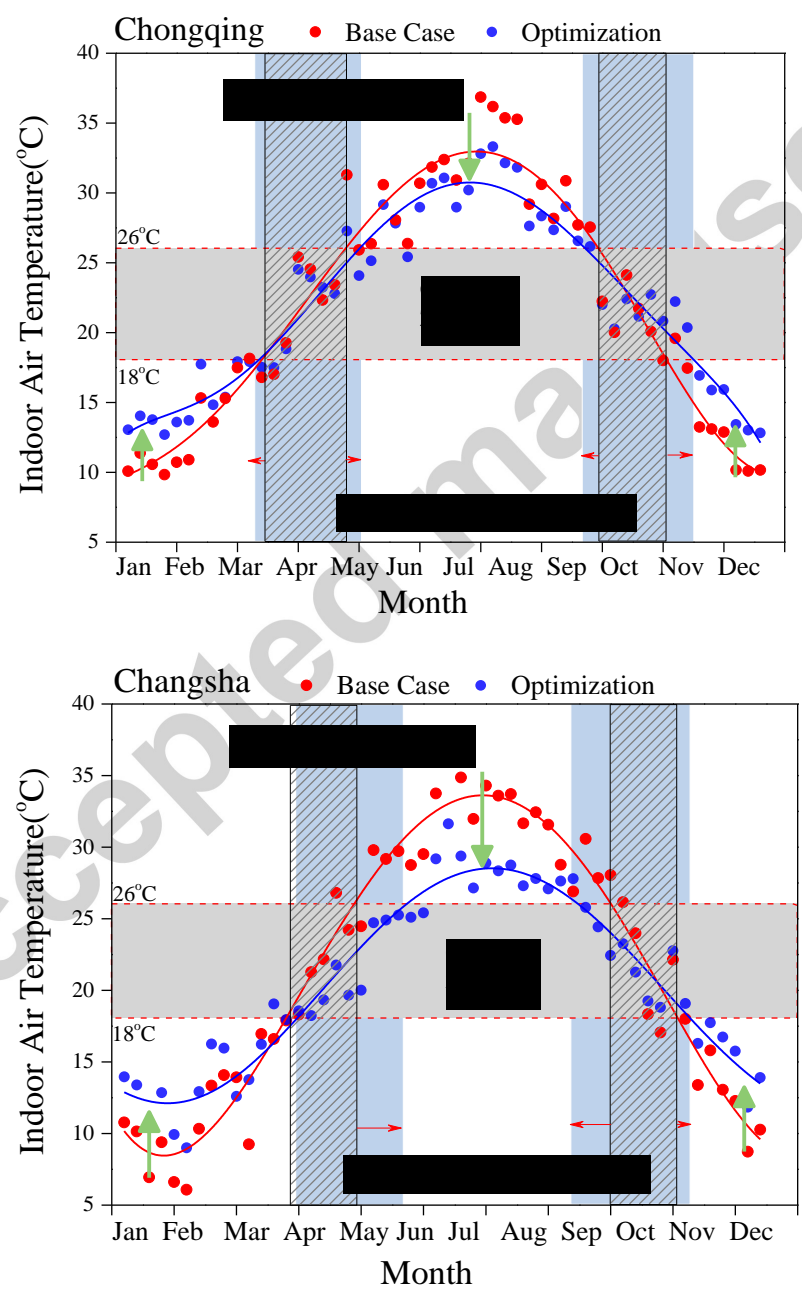


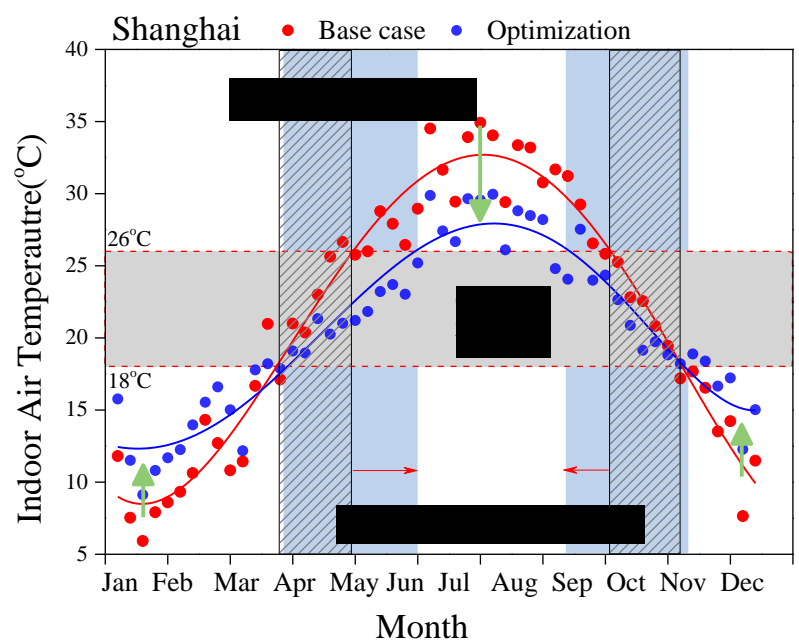

Figure 5. Weekly averaged indoor temperatures for the best (blue dots and line) and worst (red dots and line) scenario in Chongqing (top), Changsha (middle) and Shanghai (bottom).

- Overcooling $\left(T<18^{\circ} \mathrm{C}\right) \quad$ Comfort $\left(18^{\circ} \mathrm{C} \leq T \leq 26^{\circ} \mathrm{C}\right) \quad$ Overheating $\left(T>26^{\circ} \mathrm{C}\right)$
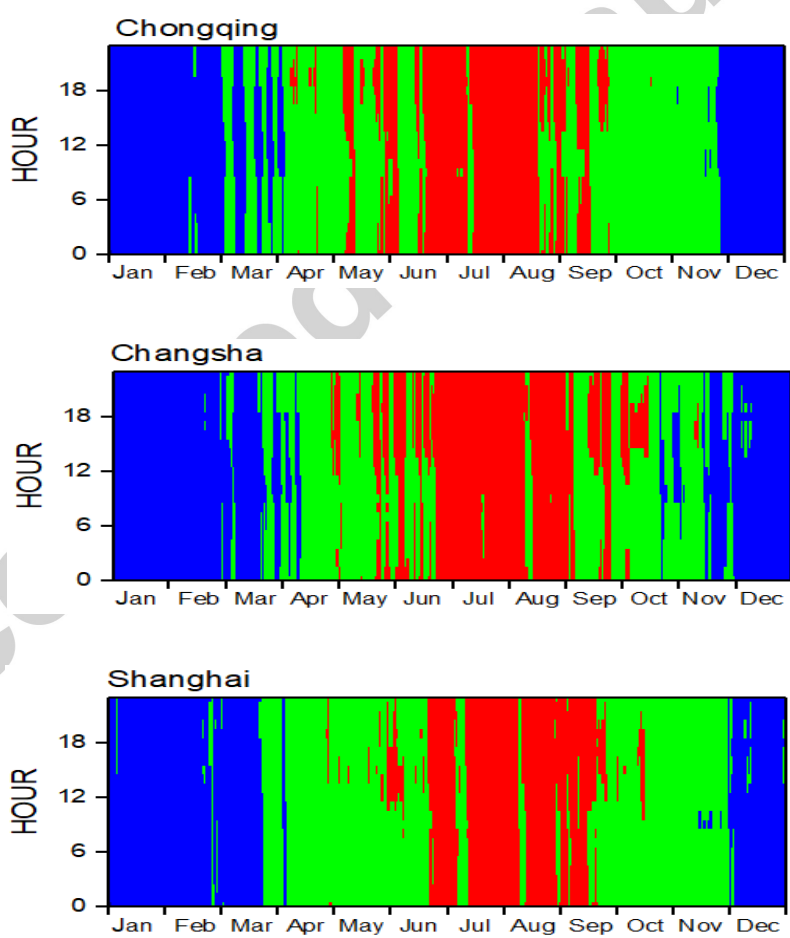

Figure 6. Annual distribution of indoor air temperature for the best scenario in Chongqing (top), Changsha (middle) and Shanghai (bottom). 


\section{ACCEPTED MANUSCRIPT}

Table 5. Summary of the best passive design solutions with their PEPS Index values

\begin{tabular}{|l|l|l|l|l|l|l|l|}
\hline & $\begin{array}{l}\text { Construction } \\
\text { age }\end{array}$ & $\begin{array}{l}\text { Building } \\
\text { orientation }\end{array}$ & $\begin{array}{l}\text { WWR } \\
\text { (south } \\
\text { façade) }\end{array}$ & $\begin{array}{l}\text { Overhangs } \\
\text { depth }(\mathbf{P F})\end{array}$ & $\begin{array}{l}\text { Walls } \\
\text { thermal } \\
\text { mass }\end{array}$ & $\begin{array}{l}\text { Natural } \\
\text { ventilation } \\
\text { rate } \\
\text { (ACH) }\end{array}$ & $\begin{array}{l}\text { PEPS } \\
\text { Index (\%) }\end{array}$ \\
\hline Chongqing & Post-2010 & $\begin{array}{l}\text { North-to-so } \\
\text { uth }\end{array}$ & 0.2 & 0.5 & heavyweight & 5 & 20 \\
\hline Changsha & Post-2010 & $\begin{array}{l}\text { North-to-so } \\
\text { uth }\end{array}$ & 0.4 & 0.5 & heavyweight & 5 & 18 \\
\hline Shanghai & Post-2010 & $\begin{array}{l}\text { North-to-so } \\
\text { uth }\end{array}$ & 0.4 & 0.5 & heavyweight & 5 & \\
\hline
\end{tabular}

\subsubsection{Chongqing}

Chongqing is known as a 'furnace city' in China because of its high outdoor temperature and humidity values, with daily average temperatures higher than $20^{\circ} \mathrm{C}$ for seven months in a year and with average humidity values always higher than $80 \%$. On the other hand, it is characterized by an hourly average sky cover of 50\% during sunlit hours, and by quite low hourly average wind velocities (less than $2 \mathrm{~m} / \mathrm{s}$ ). For all these reasons, it stands out as the warmest city among the selected ones.

Consistently, the simulations point out the need to reduce the heat flux incoming through the envelope by reducing the amount of glazed surfaces on the south-oriented façade and by shading them with external overhangs (optimal WWR of 0.2 and PF of 0.5 ). The correct orientation of the building is the north to south: it allows for taking advantage of solar gains in winter when the sun height is lower. To let these free gains help improving comfort conditions in winter, the envelope has to be well insulated (walls $\mathrm{U}$-value of $0.83 \mathrm{~W} / \mathrm{m}^{2} \mathrm{~K}$ ) and with good thermal inertia provided by heavy weight walls (see Table 4). This is helpful also for exploiting natural ventilation: in fact, best comfort conditions (3864 comfort hours in a year) are reached when the highest achievable ACH are set to 5.

Figure 5 (top row) shows the weekly averaged indoor temperatures for both the best scenario described above and the worst one pointed out from the simulations, which is characterized by old constructions (i.e. higher U-values), a WWR of 0.4 without any external overhangs, a west to east orientation and no use of natural ventilation. From this annual analysis, it is observable how the main contribution of passive solutions are appreciable during winter and transition periods, thanks to the warmer indoor environment achieved. 


\section{ACCEPTED MANUSCRIPT}

Peak summer temperatures are slightly lowered mainly because of the reduction of the heat flux incoming through the envelope when using shading devices and insulating the outer walls.

The annual indoor conditions have been further analysed by plotting indoor temperature values on a heat map chart showing the values achieved for every hour of the year (Figure 6, top row). Here, the comfort hours (i.e. those in the range of 18 to $26^{\circ} \mathrm{C}$ ) have been identified by green coloured areas, while too warm and too cold conditions are shown as red and blue patches respectively. This graph rebates how comfort conditions (44\% of annual hours) are usually achieved during transition periods, but overheating issues are still of main concern from April to October with almost $26 \%$ of hours showing indoor temperatures higher than $26^{\circ} \mathrm{C}$, and some overcooling occurrences appear in winter as well (temperatures lower than $18^{\circ} \mathrm{C}$ for $30 \%$ of the time).

\subsubsection{Changsha}

As already shown by the calculation of HDD and CDD in Table 1, Changsha presents quite harsh conditions during both winter and summer periods. Differently from Chongqing, average hourly wind values are usually greater than $2 \mathrm{~m} / \mathrm{s}$ (mainly coming from the south), the sky is less cloudy (average sky cover during sunlit hours is around 40\%) and the average monthly outdoor temperatures are higher than $20^{\circ} \mathrm{C}$ for 5 months in a year. On the other hand, temperatures as low as $5^{\circ} \mathrm{C}$ are expected during the winter season, with constantly high humidity values (daily averages higher than $80 \%$ ) throughout the year.

For such climatic conditions, the outcomes of the simulations show that the best performing configuration for the apartment block under study is given by orienting the building north to south, using a WWR of 0.4 for the south-oriented windows with the provision of external overhangs $(\mathrm{PF}=0.5)$. As far as thermal insulation is concerned, constructions used in the period post-2010 (see Table 2) represent the optimal configuration in terms of U-values.

Natural ventilation, activated with an hourly air change rate of 5, gives the best results if coupled with massive outer walls. Under these circumstances, the predicted number of comfort hours is 3227 against the 1609 hours estimated for the worst performing scenario, the last one does not make use of a natural ventilation strategy, uses poor-insulated building constructions (pre-2001 thermal characteristics shown in Table 2) with medium-weight outer walls and has the long axis of the building oriented north to south. The remaining characteristics are the same as for the best scenario. 


\section{ACCEPTED MANUSCRIPT}

The weekly averaged indoor temperatures shown in Figure 5 (middle row) for the best and worst scenarios respectively, point out how for this city natural ventilation is able not only to reduce summer peaks but also lowering the indoor temperatures during transition periods. On the other hand, the adoption of better-insulated building components is able to provide higher indoor temperatures during the winter period.

If looking at the annual distribution of indoor temperature on the heat map chart (Figure 6, middle row), it is seen that comfort hours are a bit lower than those achieved in Chongqing and amounts to around $37 \%$, while the overheating and overcooling hours accounted for $27 \%$ and $36 \%$ of the whole year.

\subsubsection{Shanghai}

Shanghai presents peculiar climatic conditions deriving from its proximity to the Eastern China sea: prevailing wind directions are from the east sector, wind velocities are higher than in Chongqing and Changsha (with hourly average values higher than $3 \mathrm{~m} / \mathrm{s}$ during night time), and the daily average humidity is around $75 \%$ throughout the year.

Average hourly outdoor temperatures are higher than $20^{\circ} \mathrm{C}$ for four months in a year, while during the coldest months they are often less than $5^{\circ} \mathrm{C}$ (with coldest temperatures of $-5^{\circ} \mathrm{C}$ ); the average sky cover is around $40 \%$ during sunlit hours.

For this climate, the best configuration has been found to have a north to south orientation, a WWR of 0.4 with a PF of 0.5 (i.e. an overhang depth equal to half the window height) for south oriented windows, heavy weight outer walls and constructions finely insulated (the optimal U-values pertain to the post 2010 construction period).

Again, the optimal natural ventilation rate and orientation configuration is $5 \mathrm{ACH}$ and north-to-south respectively for Shanghai. The worst configuration differs from the best one because it does not make use of natural ventilation and uses poorly insulated constructions (pre-2001 with the highest U-values). The remaining geometrical and thermal characteristics are the same of the best configuration.

The analysis of the weekly averaged indoor temperatures (Figure 5, bottom row) reveals a trend similar to that of Changsha for the best scenario: temperatures are lower in summer and during transition periods, while during winter they are consistently higher.

The analysis of the indoor conditions for the best scenario on the heat map chart of Figure 6 (bottom row) shows good comfort conditions for $46 \%$ of the time (in the worst case this 


\section{ACCEPTED MANUSCRIPT}

figure is around 22\%). Nevertheless, mechanical devices are required for the remaining of time especially during the winter season, as shown by the blue patches in the heat map for the first three months and for the last month of the year respectively.

\subsection{Peak loads and annual energy consumption}

Heating (left column) and cooling (right column) peak loads are shown in Figure 7 for the best and worst scenarios identified by the simulations for the coldest and warmest week in every city, respectively. Comments about the specific figures achieved in every city are provided in the following subsections together with the energy demand calculation.

\section{Chongqing}
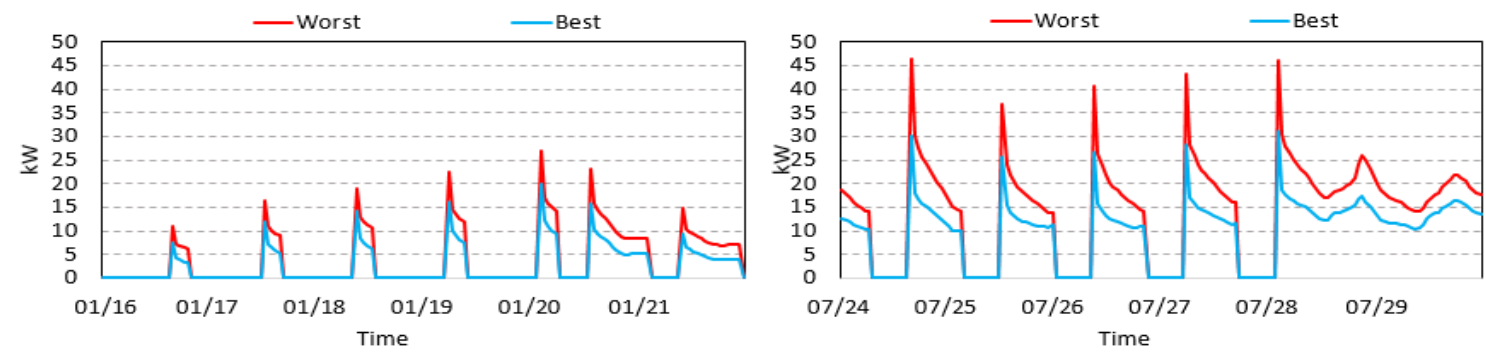

\section{Changsha}
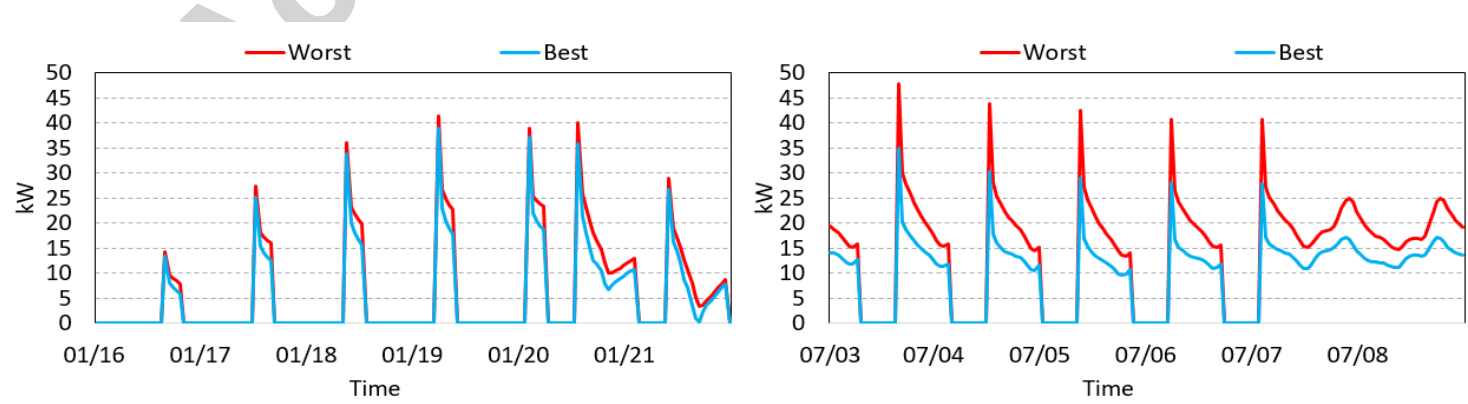

\section{Shanghai}




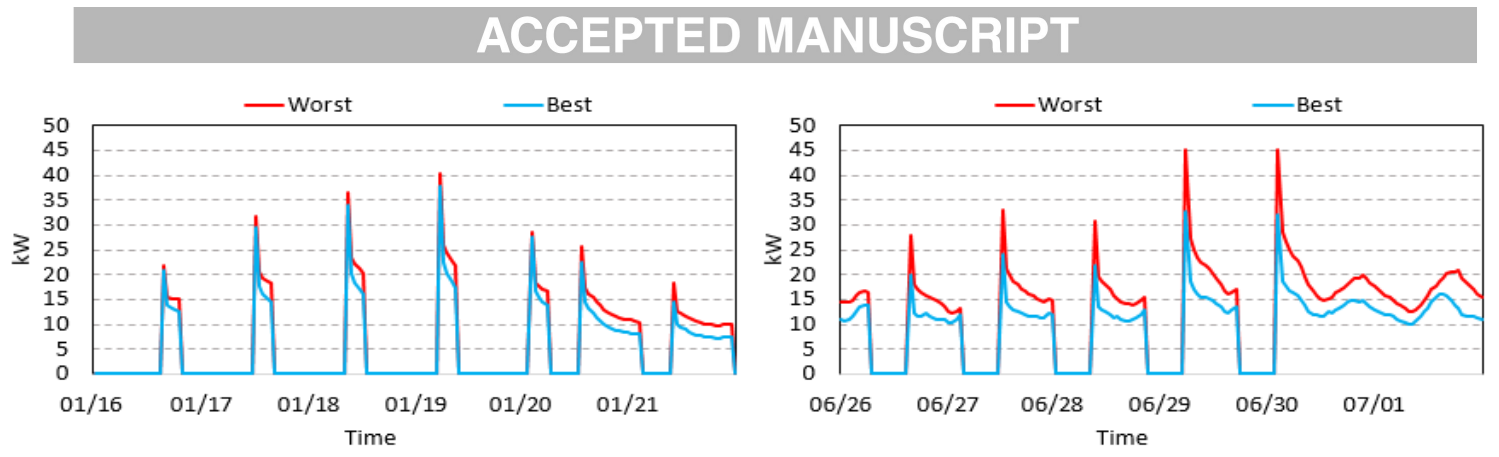

Figure 7. Heating (on the left side) and cooling (on the right side) loads during extreme weeks in Chongqing (top), Changsha (middle) and Shanghai (bottom)

According to the methodology explained above, the estimate of the energy demand has been carried out under the two different scenarios of $24 \mathrm{~h} \mathrm{HVAC}$ available and of a typical user profile respectively. In order to appraise how energy-efficient and increasingly common devices like air-to-air heat pumps can help reducing the electricity consumption for air conditioning purposes, the energy demand from the simulations (ideal loads system applied, i.e. an ideal system of infinite capacity) has been converted into electricity consumption for heating and cooling. This is done by dividing the culmulated hourly loads for the average $\mathrm{COP}$ values provided by the standards during winter $(\mathrm{COP}=1.9)$ and summer $(\mathrm{COP}=2.3)$ operation.

The annual energy consumption of the best design solutions are summarized in Table 6, including both scenarios of energy consumption with an ideal loads system and with an air-to-air heat pump. The following detailed discussion in sections 4.2.1 to 4.2.3 will only deal with the electricity consumption of the typical user profile operation for the sake of brevity. Figure 8 shows the monthly heating and cooling electricity consumption and the correspondent indoor air temperature ranges for best and worst cases of the three study cities. From this figure, we can see that the worse cases are strongly improved with energy reductions due to the application of passive measures. Moreover, it is noted that the indoor air temperatures are mostly outside the comfort range during the non-operation time. When comparing the user profile and $24 \mathrm{~h}$ operation, the cooling and heating electricity consumption for user profile is by far lower than $24 \mathrm{~h}$ operation.

Table 6. Summary of the energy consumption of the best passive design solutions $\left(\mathrm{kWhm}^{-2}\right)$

\begin{tabular}{|l|l|l|}
\hline \multirow{2}{*}{} & \multicolumn{2}{|c|}{ Energy consumption from an ideal loads system } \\
\cline { 2 - 3 } & 24h operation & \\
\hline
\end{tabular}




\begin{tabular}{|c|c|c|c|c|c|c|c|c|c|c|}
\hline \multicolumn{11}{|c|}{ ACCEPTED MANUSCRIPT } \\
\hline & \multicolumn{2}{|c|}{ Heating } & \multicolumn{2}{|c|}{ Cooling } & \multirow[t]{2}{*}{ TOT } & \multicolumn{2}{|c|}{ Heating } & \multicolumn{2}{|c|}{ Cooling } & \multirow[t]{2}{*}{ TOT } \\
\hline & Sensible & Latent & Sensible & Latent & & Sensible & Latent & Sensible & Latent & \\
\hline Chongqing & 7 & 4.6 & 41.4 & 35.2 & 88.2 & 7.4 & 4.1 & 29.3 & 25.1 & 65.9 \\
\hline Changsha & 17.2 & 11 & 43.9 & 37.6 & 109.7 & 13.3 & 7.2 & 30.2 & 26.7 & 77.4 \\
\hline \multirow[t]{5}{*}{ Shanghai } & 15.9 & 11.1 & 37 & 31.9 & 95.9 & 12.3 & 7.2 & 25.1 & 22.1 & 66.7 \\
\hline & \multicolumn{10}{|c|}{ Air-to-air heat pump } \\
\hline & \multicolumn{5}{|c|}{ 24h operation } & \multicolumn{5}{|c|}{ User profile } \\
\hline & \multicolumn{2}{|c|}{ Heating } & \multicolumn{2}{|c|}{ Cooling } & TOT & \multicolumn{2}{|c|}{ Heating } & \multicolumn{2}{|c|}{ Cooling } & TOT \\
\hline & Sensible & Latent & Sensible & Latent & & Sensible & Latent & Sensible & Latent & \\
\hline Chongqing & 3.7 & 2.4 & 18.0 & 15.3 & 39.4 & 3.9 & 2.1 & 12.7 & 10.9 & 29.6 \\
\hline Changsha & 9.1 & 5.8 & 19.1 & 16.3 & 50.3 & 7.0 & 3.8 & 13.1 & 11.6 & 35.5 \\
\hline Shanghai & 8.4 & 5.8 & 16.1 & 13.9 & 44.2 & 6.5 & 3.8 & 10.9 & 9.6 & 30.8 \\
\hline
\end{tabular}




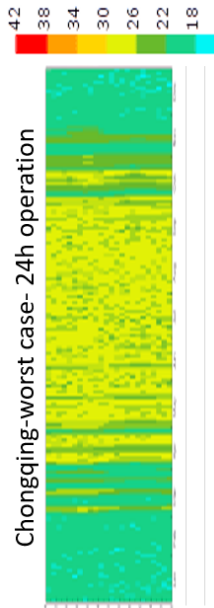

Кер fo ınoч

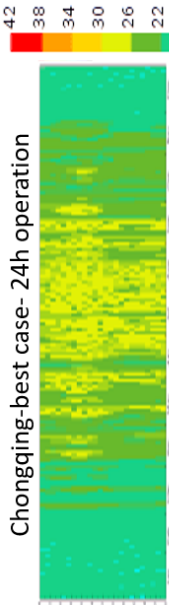

кер ло лnou

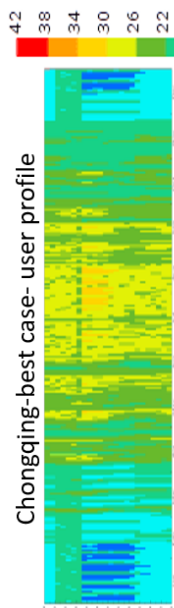

кер to лnou
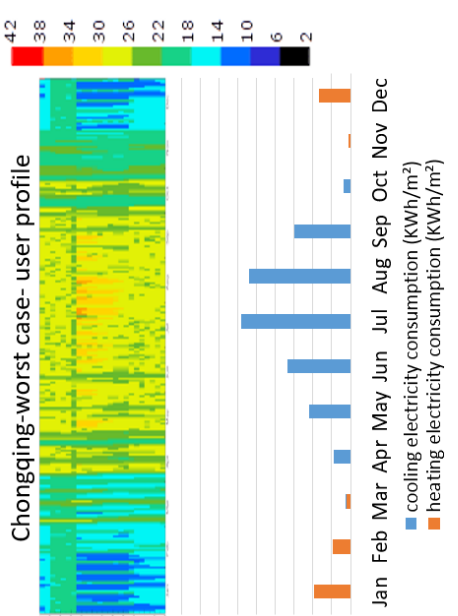

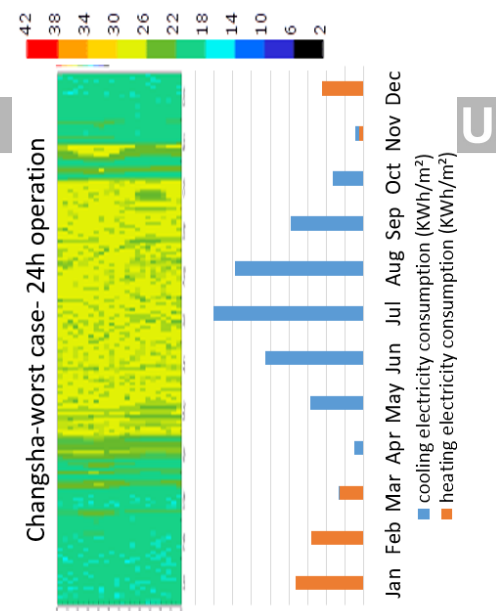

лер ло лnоч

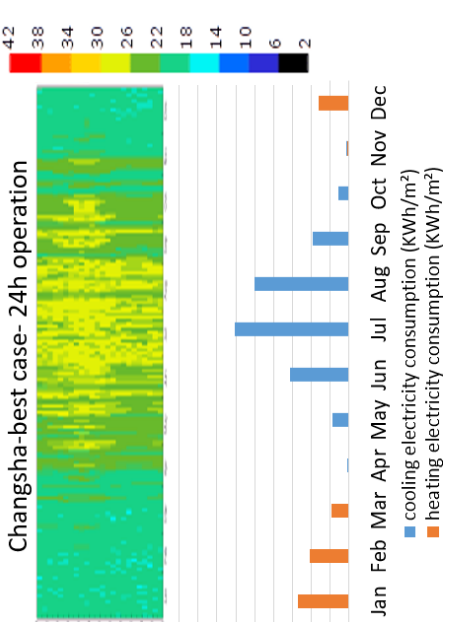

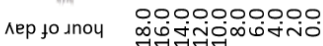

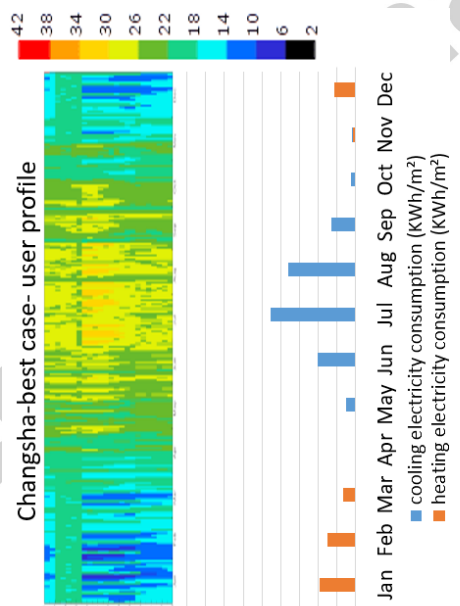

^ер ло иnоч

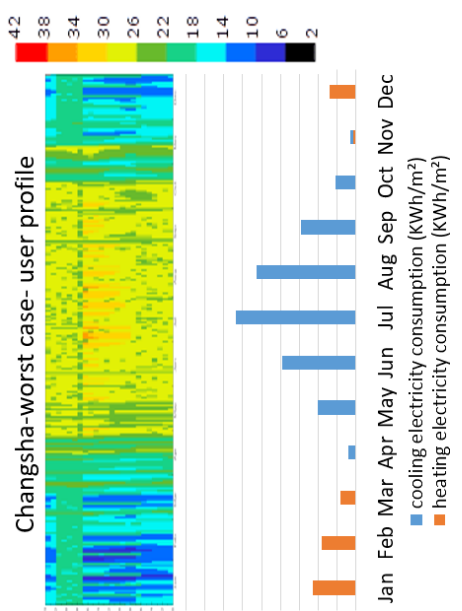

мер ло גnoy

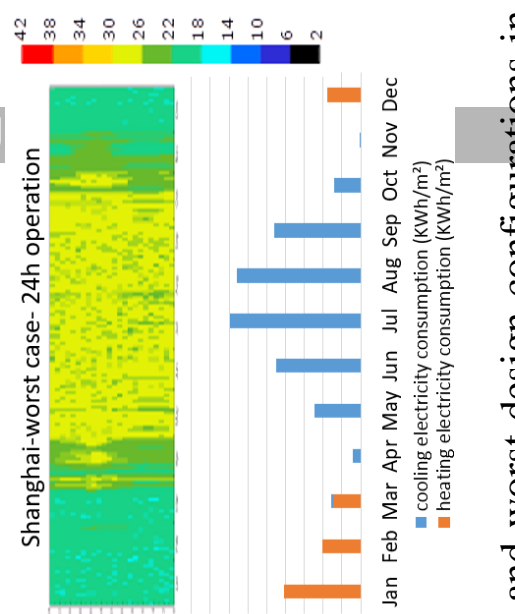

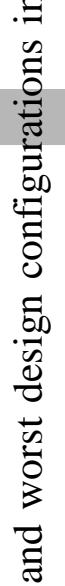

кер to нолоч

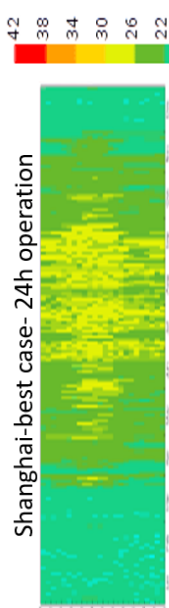

ปั

$\stackrel{0}{=}$

ث

తo
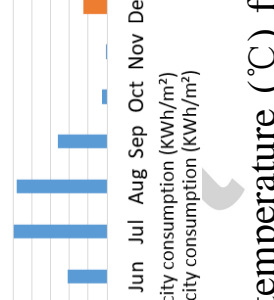

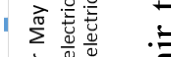

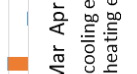

드용

든
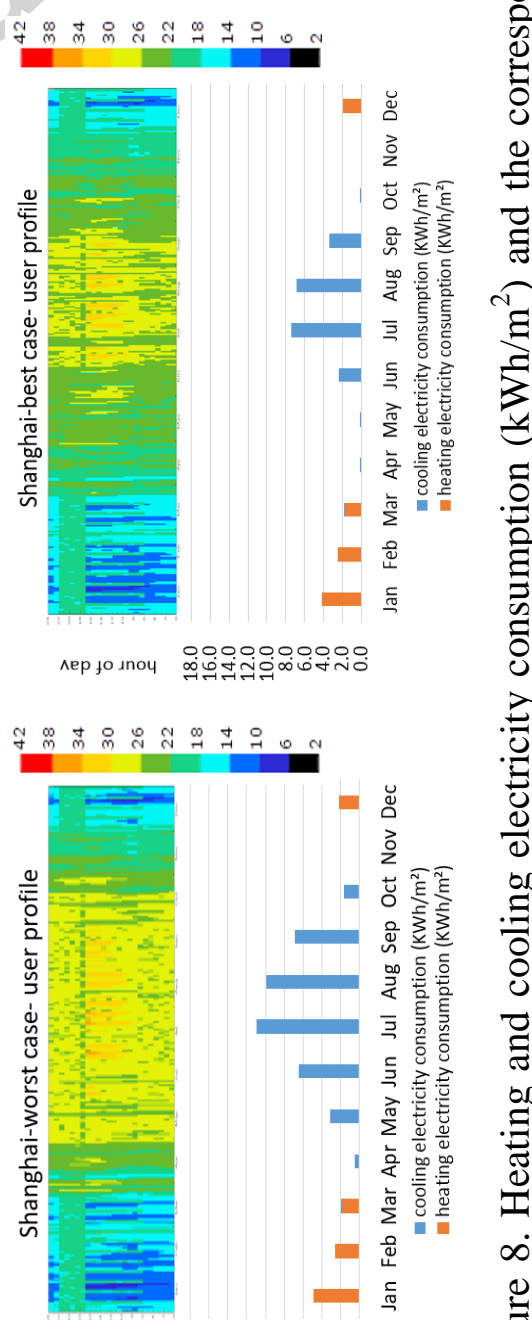


\subsubsection{Chongqing}

Section 4.1.1 showed how the use of passive solutions alone is able to guarantee $44 \%$ of comfort hours throughout the year, while this figure is around $24 \%$ in the worst case scenario. This means that, for the comfort boundaries adopted in this study, heating and cooling are still needed in the remaining of the year to reach satisfactory indoor conditions. Nonetheless, noticeable energy savings (around 42.5\%) are expected when comparing the best performing case with the worst one, making the final energy energy consumption achievable by the best configuration equal to $6.0 \mathrm{kWh} / \mathrm{m}^{2}$ for space heating and $23.6 \mathrm{kWh} / \mathrm{m}^{2}$ for space cooling.

It is interesting to note that, due to the high outdoor humidity values, sensible and latent cooling energy demand are quite close with each other.

Another beneficial effect of using passive design measures is given by the reduction of peak loads, which helps reducing the size of the mechanical devices in the design stage and thus their consumption and running costs. Figure 7 depicts the heating (on the left side) and cooling (on the right side) loads during the two extreme weeks of the year in Chongqing. Here, it is possible to appreciate how the peaks are strongly reduced in the best-case scenario and the loads are consistently lower throughout the time. This leads to choose a size for the heat pump in the case study building of around $20 \mathrm{~kW}$ for heating and of $33 \mathrm{~kW}$ for cooling, against the $27 \mathrm{~kW}$ and $44 \mathrm{~kW}$ needed in the worst case respectively.

\subsubsection{Changsha}

Also for Changsha, the spikes that characterize the loads profiles for the worst case scenario (Figure 7, red lines) are less pronounced in the best performing configuration (cyan lines), and the loads are more consistently lower in time. This brings choosing a heating device with a peak power of around $39 \mathrm{~kW}$ (against the $42 \mathrm{~kW}$ needed in the worst scenario), and a cooling device of $35 \mathrm{~kW}$ capacity (against the worst case of $48 \mathrm{~kW}$ ).

As a result, the final EUI for space heating and cooling are $10.8 \mathrm{kWh} / \mathrm{m}^{2}$ and $24.7 \mathrm{kWh} / \mathrm{m}^{2}$ respectively for the best model, while being of $12.8 \mathrm{kWh} / \mathrm{m}^{2}$ and $44.1 \mathrm{kWh} / \mathrm{m}^{2}$ for the worst-case scenario instead. Also in this case the high outdoor humidity levels render the energy consumption due to latent cooling loads comparable to that due to sensible cooling loads. 


\subsubsection{Shanghai}

For Shanghai the estimated energy savings with respect to the worst scenario are slightly less than that for Chongqing, and amount to around $39.8 \%$ (from $51.2 \mathrm{kWh} / \mathrm{m}^{2}$ to $30.8 \mathrm{kWh} / \mathrm{m}^{2}$ ). Also for this city thermal loads show to be lower in the best configuration (Figure 7), and thus are the sizes requested for the heating and cooling devices (around $37 \mathrm{~kW}$ for heating and $33 \mathrm{~kW}$ for cooling against $40 \mathrm{~kW}$ for heating and $45 \mathrm{~kW}$ for cooling in the worst configuration).

\subsection{Discussion of the simulation outcomes and design suggestions for the different cities}

The outcomes of hourly dynamic simulations show how the best performing scenarios in each city share some common characteristics (see Table 5); in particular, the best plan orientation is the north to south, which allows to fully exploit free solar gains in winter by reducing overheating risk in summer when the sun height is higher. Furthermore, the use of natural ventilation strategies had a positive effect on indoor thermal comfort. The different design solutions suggested in section 4.1 for each city directly stem from local climate peculiarities such as intensity of solar radiation and prevailing wind speeds.

On the other hand, it is interesting to note that the worst performing configurations are the same in each city: the orientation of the apartment block is west to east, constructions show high U-values (older constructions), high WWR without the use overhangs and natural ventilation strategies are not employed.

A main novelty of this study if compared to existing ones is the consideration of both sensible and latent loads in the energy analysis, an issue of main concern given the high outdoor humidity values achieved throughout the year in the HSCW zone. In fact, Table 6 clearly shows that not only the sensible and latent cooling loads are of almost the same magnitude, but even during the heating season there is a need to dehumidify the indoor (latent loads are more than half of sensible ones).

Finally, it is worth to note how some simulation assumptions may affect the results discussed above. In particular, the choice of a comfort zone band of 18 to $26^{\circ} \mathrm{C}$ and of 30 to $70 \%$ relative humidity affect both the comfort and energy analyses in absolute terms, and this explains why comfort and energy performance improvements expressed in terms of PEPS Index and energy savings may appear not enormous. However, the relative comparison 


\section{ACCEPTED MANUSCRIPT}

among different configurations is not affected: in other words, the best and worst configuration still hold if changing these temperature thresholds. In addition, the final actual energy consumption for heating and cooling depend on the performance of the heating and cooling system. There is a space to exploit higher performance of air conditioning system in order to achieve the targeted energy consumption set up by the standard.

\section{Conclusions}

An extensive parametric analysis based on dynamic thermal simulations has been carried out with the aim of showing how typical passive design solutions can improve indoor comfort conditions, while reducing the energy needs, of a typical apartment block located in different cities of the Hot Summer and Cold Winter zone in China. The cities chosen for this purpose are located respectively in the upper (Chongqing), middle (Changsha) and downstream (Shanghai) of the Yangtze River. The main conclusions of this study are the following:

- By applying proper passive design measures, it is possible to extend the non-heating and cooling period. The PEPS Indexes of the best passive design configurations are $18 \%$ in Changsha, 20\% in Chongqing and 24\% in Shanghai;

- The best passive design solutions have some common characteristics, namely a north to south orientation, well-insulated building envelopes, shading PF of 0.5 and a natural ventilation rate of exceeding $5 \mathrm{ACH}$. The optimum WWR for south façade varies according to climate differences, the hottest city of Chongqing requiring the smallest amount of glazed surfaces (WWR of 0.2) on the south façade, while Changsha and Shanghai have optimal WWR of 0.4. Under a typical occupancy profile, the electricity savings are around $51.7 \%$ in Chongqing, 37.6\% in Changsha and 39.8\% in Shanghai when the best performing scenarios are compared to the worst ones;

- Mechanical systems are still necessary to control the indoor environment during the hottest and coolest periods. Devices using low-grade energy sources such as air source heat pump, renewable energy production, improved coefficient of performance of the energy systems (COP values) and optimised operation strategies are sought to reach lower energy consumption;

- The integrated approach including climate responsive passive design to extend the non-heating and cooling period and the use of high-efficiency low-grade energy systems is the direction towards the achievement of comfortable and low-energy houses. 


\section{ACCEPTED MANUSCRIPT}

This work represents a first study about passive design of residential buildings in the HSCW zone in China; further research is planned to include detailed analysis about different house typologies and occupancy behaviour.

\section{Acknowledgements}

The research is jointly sponsored by the Natural Science Foundation of China (NSFC Grant No: 51561135002) and the UK Engineering and Physical Sciences Research Council (EPSRC EP/N009797/1). The research findings will support the National Key R\&D Programme 'Solutions to Heating and Cooling of Buildings in the Yangtze River Region' (Grant No: 2016YFC0700301). The authors would like to thank Ms. Chenqiu Du, Mr. Jie Xiong and Mr. Hongyuan Jia for their technical assistant.

\section{References}

[1] R. Yao, K. Steemers, B. Li, Introduction to Sustainable Urban and Architectural Design. In: R. Yao, K. Steemers, B. Li (eds.), Introduction to Sustainable Urban and Architectural Design. China Architecture and Building Press, China, 2006.

[2] V. Olgyay, A. Olgyay, Design With Climate: Bioclimatic Approach to Architectural Regionalism, $1^{\text {st }}$ Edition. Princeton University Press Princeton, New Jersey, 1963.

[3] B. Givoni. Man, Climate and Architecture, Elsevier Publ. Co. Amsterdam, 1969.

[4] M.S. Sodha, N.K. Bansal, P.K. Bansal, A. Kumar, M.A.S. Malik, Solar Passive Building, Pergamon Press, Oxford, 1986.

[5] S.V. Szokolay, Solar Energy and Building, $2^{\text {nd }}$ Edition, The Architectural Press, London; 1987

[6] N. Lechner, Heating, Cooling, Lighting: Design Methods for Architects, John Wiley \& Sons Inc, 1991.

[7] J. Schnieders, W. Feist, L. Rongen, Passive Houses for different climate zones, Energy Build. 105 (2015) 71-87. doi:10.1016/j.enbuild.2015.07.032.

[8] A. Consoli, V. Costanzo, G. Evola, L. Marletta, ScienceDirect Refurbishing an existing apartment block in Mediterranean climate : towards the Passivhaus standard, Energy Procedia. 0 (2015) 1-10. doi:10.1016/j.egypro.2017.03.201.

[9] B. Ford, R. Schiano-Phan, D. Zhongcheng, Passive-On Project The Passivhaus standard in European warm climates: Part 3 Design guidelines for comfortable low energy homes, (2007) 53. doi:10.1039/9781847551740-FP009. 


\section{ACCEPTED MANUSCRIPT}

[10] Passive Low Energy Architecture, http://plea-arch.org/ (accessed May 2017)

[11] EU, Directive 2010/31/EU of the European Parliament and of the Council of 19 May 2010 on the energy performance of buildings (recast), Off. J. Eur. Union. (2010) 13-35. doi:doi:10.3000/17252555.L_2010.153.eng.

[12] J. Bouillot, Climatic design of vernacular housing in different provinces of China, J. Environ. Manage. 87 (2008) 287-299. doi:10.1016/j.jenvman.2006.10.029.

[13] W. Renping, C. Zhenyu, An ecological assessment of the vernacular architecture and of its embodied energy in Yunnan, China, Build. Environ. 41 (2006) 687-697. doi:10.1016/j.buildenv.2005.02.023.

[14] X. Shi, W. She, H. Zhou, Y. Zhang, F. Shi, W. Chen, Thermal upgrading of Hui-style vernacular dwellings in China using foam concrete, Front. Archit. Res. 1 (2012) 23-33. doi:10.1016/j.foar.2012.02.001.

[15] X. Du, R. Bokel, A. van den Dobbelsteen, Building microclimate and summer thermal comfort in free-running buildings with diverse spaces: A Chinese vernacular house case, Build. Environ. 82 (2014) 215-227. doi:10.1016/j.buildenv.2014.08.022.

[16] X. Zhu, J. Liu, L. Yang, R. Hu, Energy performance of a new Yaodong dwelling, in the Loess Plateau of China, Energy Build. 70 (2014) 159-166. doi:10.1016/j.enbuild.2013.11.050.

[17] S. Wang, F. Shi, B. Zhang, J. Zheng, The Passive Design Strategies and Energy Performance of a Zero-energy Solar House : Sunny Inside in Solar Decathlon China 2013, (2016) 543-548. doi:10.3130/jaabe.15.543.

[18] Energy Foundation, Feasibility Study on Promoting passive Residential Housing in China (2013) (in Chinese).

[19] Dan ning Yang, Di Wu, Cong hong Liu, Enclosure System of Chinese Passive House:Passive house in Chinese cold zone and severe cold zone as examples, Building Energy Efficiency, 2017(1) (in Chinese).

[20] Wang Lihua, Exploration and Practice of Passive Building Technology System in Hot Summer and Cold Winter Zone, Construction Science and Technology, 2015(15) 67-71 (in Chinese).

[21] Peng Qu, Guanhui Li, Lie Li, The application strategy of the passive house in Hot Summer and Cold Winter region is first explored, Engineering Technology, 00263-00263 (in Chinese).

[22] Pan Li, Xu Qiang, Study on the Technical Route of Passive Ultra - low Energy Consumption in Shanghai, Construction Science and Technology. 2015(23) 22-23 (in Chinese).

[23] Wang Jing, Summarization and Thoughts on Application Experience of Passive Room External Thermal Insulation System in Hot Summer and Cold Winter Zone, Construction Science and Technology, 2014(8) 47-51 (in Chinese).

[24] Weiqi Zhao, Bo Jiang, Qu Yang, Practice of Passive Building in Hot Summer and Cold Winter Zone, Landsea Bruck Passive House, The 11th International Green Building and Building Energy Conservation Conference \& New Technology and Products Expo Proceedings - S01 Green Building Design Theory, Technology and 


\section{ACCEPTED MANUSCRIPT}

Practice. 2015(3): 53-58 (in Chinese).

[25] MOHURD. Standard of Climate Regionalization for Architecture, GB50178-93, 1993 (in Chinese).

[26] Tsinghua University Building Energy Research Centre (TUBERC): 2014 Annual Report on China Building Efficiency, Architecture and Building Press, Beijing, 2014 (in Chinese).

[27] S. Hu, D. Yan, Y. Cui, S. Guo, Urban residential heating in hot summer and cold winter zones of China-Status, modeling, and scenarios to 2030, Energy Policy. 92 (2016) 158-170. doi:10.1016/j.enpol.2016.01.032.

[28] R. Yao, K. Steemers, N. Li, An assessment tool for natural ventilation in strategic building design. In: 22nd conference on passive low energy architecture, 13-16 November, 2005 , Beirut, Lebanon.

[29] S.B. Sadineni, S. Madala, R.F. Boehm, Passive building energy savings: A review of building envelope components, Renew. Sustain. Energy Rev. 15 (2011) 3617-3631. doi:10.1016/j.rser.2011.07.014.

[30] B.P. Jelle, Traditional, state-of-the-art and future thermal building insulation materials and solutions - Properties, requirements and possibilities, Energy Build. 43 (2011) 2549-2563. doi:10.1016/j.enbuild.2011.05.015.

[31] U. Larsson, B. Moshfegh, M. Sandberg, Thermal analysis of super insulated windows (numerical and experimental investigations), Energy Build. 29 (1999) 121-128. doi:10.1016/S0378-7788(98)00041-3.

[32] R. Urquhart, R. Richman, G. Finch, The effect of an enclosure retrofit on air leakage rates for a multi-unit residential case-study building, Energy Build. 86 (2015) 35-44. doi:10.1016/j.enbuild.2014.09.079.

[33] A. Sfakianaki, K. Pavlou, M. Santamouris, I. Livada, M.N. Assimakopoulos, P. Mantas, A. Christakopoulos, Air tightness measurements of residential houses in Athens, Greece, Build. Environ. 43 (2008) 398-405. doi:10.1016/j.buildenv.2007.01.006.

[34] H. Akbari and T.R. Borgers, Free convective laminar flow within the Trombe wall channel, Solar Energy 22 (1979) 165-74

[35] R.O. Warrington and T.A. Ameel, Experimental studies natural convection in partitioned enclosures with a Trombe wall geometry, Solar Energy-Transaction of the ASME 117 (1995) 16-21

[36] P. Pinel, C.A. Cruickshank, I. Beausoleil-Morrison, A. Wills, A review of available methods for seasonal storage of solar thermal energy in residential applications, Renew. Sustain. Energy Rev. 15 (2011) 3341-3359. doi:10.1016/j.rser.2011.04.013.

[37] R. Barzin, J.J.J. Chen, B.R. Young, M.M. Farid, Application of PCM energy storage in combination with night ventilation for space cooling, Appl. Energy. 158 (2015) 412-421. doi:10.1016/j.apenergy.2015.08.088.

[38] K.J. Watson, Understanding the role of building management in the low-energy performance of passive sustainable design: Practices of natural ventilation in a UK office building, Indoor Built Environ. 24 (2015) 999-1009. 
doi:10.1177/1420326X15601478

[39] E. Perera E and L. Parkins, Build tight - ventilate right, Building Services, Chartered Institution of Building Services Engineers, London, June 1992, 37-38.

[40] S.M. Porritt, P.C. Cropper, L. Shao, C.I. Goodier, Ranking of interventions to reduce dwelling overheating during heat waves, Energy Build. 55 (2012) 16-27. doi:10.1016/j.enbuild.2012.01.043.

[41] R. Yao, K. Steemers, N. Baker, Strategic design and analysis method of natural ventilation for summer cooling, Build. Serv. Eng. Res. Technol. 26 (2005) 315-335. doi:10.1191/0143624405bt139oa.

[42] A. Tzempelikos, A.K. Athienitis, The impact of shading design and control on building cooling and lighting demand, Sol. Energy. 81 (2007) 369-382. doi:10.1016/j.solener.2006.06.015.

[43] V. Costanzo, G. Evola, A. Gagliano, L. Marletta, F. Nocera, Study on the application of cool paintings for the passive cooling of existing buildings in mediterranean climates, Adv. Mech. Eng. 2013 (2013). doi:10.1155/2013/413675.

[44] R. Kumar, S.C. Kaushik, Performance evaluation of green roof and shading for thermal protection of buildings, Build. Environ. 40 (2005) 1505-1511. doi:10.1016/j.buildenv.2004.11.015.

[45] I. Jaffal, S.-E. Ouldboukhitine, R. Belarbi, A comprehensive study of the impact of green roofs on building energy performance, Renew. Energy. 43 (2012) 157-164. doi:10.1016/j.renene.2011.12.004.

[46] W.J. Hee, M.A. Alghoul, B. Bakhtyar, O. Elayeb, M.A. Shameri, M.S. Alrubaih, K. Sopian, The role of window glazing on daylighting and energy saving in buildings, Renew. Sustain. Energy Rev. 42 (2015) 323-343. doi:10.1016/j.rser.2014.09.020.

[47] MOHURD. Design Standard for Energy Efficiency of Residential Buildings in Hot Summer and Cold Winter Zone, JGJ 134-2001, 2001 (in Chinese).

[48] MOHURD. Design Standard for Energy Efficiency of Residential Buildings in Hot Summer and Cold Winter Zone, JGJ 134-2010, 2010 (in Chinese).

[49] National Standard of the People's Republic of China. GB 50736-2012: design code for heating ventilation and air conditioning of civil buildings, Beijing: China Architecture \& Building Press, 2012 (in Chinese).

[50] H. Liu, Y. Wu, B. Li, Y. Cheng, R. Yao, Seasonal variation of thermal sensations in residential buildings in the Hot Summer and Cold Winter zone of China, Energy Build. 140 (2017) 9-18. doi:10.1016/j.enbuild.2017.01.066.

[51] V. Costanzo, M. Donn, Thermal and visual comfort assessment of natural ventilated office buildings in Europe and North America, Energy Build. 140 (2017) 210-223. doi:10.1016/j.enbuild.2017.02.003.

[52] M. Kottek, J. Grieser, C. Beck, B. Rudolf, F. Rubel, World map of the Köppen-Geiger climate classification updated, Meteorol. Zeitschrift. 15 (2006) 259-263. doi:10.1127/0941-2948/2006/0130.

[53] ASHRAE, ASHRAE Handbook Fundamentals, American Society of Heating, 


\section{ACCEPTED MANUSCRIPT}

Refrigerating and Air-Conditioning Engineers, Inc., Atlanta, 2009

[54] M. Trebilcock, B. Piderit, J. Soto, R. Figueroa, A parametric analysis of simple passive strategies for improving thermal performance of school classrooms in Chile, Archit. Sci. Rev. 8628 (2016) 1-15. doi:10.1080/00038628.2016.11502519

[55] X. Chen, H. Yang, Y. Wang, Parametric study of passive design strategies for high-rise residential buildings in hot and humid climates: miscellaneous impact factors, Renew. Sustain. Energy Rev. 69 (2017) 442-460. doi:10.1016/j.rser.2016.11.055

[56] S. Stevanović, Parametric study of a cost-optimal, energy efficient office building in Serbia, Energy. 117 (2016) 492-505. doi:10.1016/j.energy.2016.06.048.

[57] J. L. M. Hensen, R. Lamberts, Building Performance Simulation for Design and Operation, $1^{\text {st }}$ Edition. Spon Press, Abingdon, 2011.

[58] J. A. Clarke, Energy Simulation in Building Design, $2^{\text {nd }}$ Edition. Routledge, Abingdon, 2001.

[59] L Jankovic, Designing Zero Carbon Buildings: Using Dynamic Simulation Methods, $2^{\text {nd }}$ Edition. Routledge, Abingdon, 2017.

[60] US Department of Energy, EnergyPlus Version 8.4, 2014 (accessed April 2017) http://apps1.eere.energy.gov/buildings/energyplus.

[61] T. Hu, H. Yoshino, Z. Jiang, Analysis on urban residential energy consumption of Hot Summer \& Cold Winter Zone in China, Sustain. Cities Soc. 6 (2013) 85-91. doi:10.1016/j.scs.2012.09.001.

[62] E. Naboni, A. Malcangi, Y. Zhang, F. Barzon, Defining the energy saving potential of architectural design, Energy Procedia. 83 (2015) 140-146.

doi:10.1016/j.egypro.2015.12.204.

\section{Highlights:}

- Passive measures for the residential buildings in the Yangtze River Valley are studied;

- An index called PEPS (Potential Effectiveness of Passive Solutions) is introduced to assess the effectiveness ;

- The PEPSs are 18\%, 20\% and 24\% for Changsha, Chongqing and Shanghai respectively;

- Passive measures can significantly extend non heating/cooling demand period and the peak load demand;

- An integrated solution of passive, active and operational behavioural is the key strategy 